\title{
FORGOTTEN GUARDIANS AND MATTHEW 18:10
}

\author{
Erkki Koskenniemi
}

\begin{abstract}
Summary
'See that you do not look down on one of these little ones. For I tell you that their angels in heaven always see the face of my Father in heaven' (Matt. 18:10 NIV). Modern commentators have not reached a consensus on the context of this verse, nor on the angels mentioned. First, whether those who are guarded are children or ordinary Christians is undecided. Secondly, some scholars deny that single Christians have an individual guardian angel. However, because early Jewish and Christian sources have by no means been thoroughly researched, evidence found thus far can probably help clarify the kind of angels Jesus was referring to. Surprisingly, angels whose mission was to avenge the evil made to children have been widely overlooked by scholars.
\end{abstract}

\section{The Verse and the Context}

The verse is part of 18:1-35, which is one of the five long speeches of Jesus and deals with life in the congregation. This speech can justly ${ }^{1}$ be divided into two parts, 1-14 and 15-35. In the first part, verses 1-5 and 6-9 are free renderings of Mark 9:33-37 and 9:42-47. The rest of the first part corresponds mainly with Luke ('Saying Source'). Verse 10, which is the subject of this article, is included only in Matthew, and it leads to his version of the parable of the lost sheep. ${ }^{2}$

1 U. Luz, Matthew 8-20: A Commentary (Minneapolis: Hermeneia, 2001): 422-24 considers the structure of the passage more complex than other scholars.

2 See, for example, J. Gnilka, Das Matthäusevangelium. II Teil: Kommentar zu Kap. 14,1-28,20 und Einleitungsfragen (HTKTNT; Freiburg, Basel, Wien, 1988): 119-12; W. Wiefel, Das Evangelium nach Matthäus (Berlin: Evangelische Verlagsanstalt, 1998): 318-19. 


\section{Mıкрoí: Children or Ordinary Christians?}

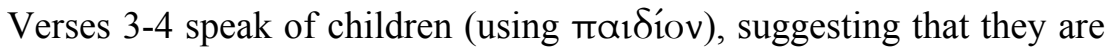

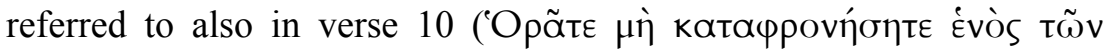

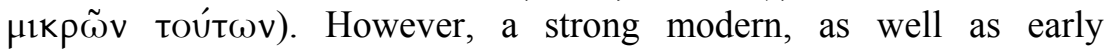
Christian, tradition of interpretation considers the words as referring to ordinary Christians.

The first sense of $\mu 1 \mathrm{k} p o$ ó is, of course, 'small' or 'young'. However, it is used of persons of lesser importance very early already, as $\mu$ '́ $\gamma \alpha$ S

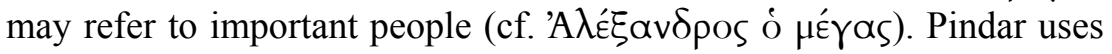

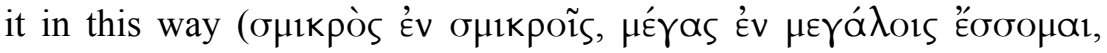

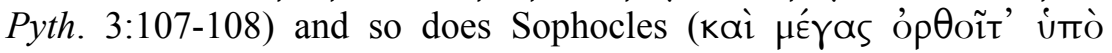

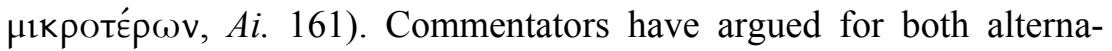
tives, mainly for the second one.

1) A few commentators claim that $\mu 1 \mathrm{k}$ poí in verse 10 means exclusively children. However, a conclusion that it also specifically includes children is not unusual. Filson opts for this alternative, ${ }^{3}$ and Gundry, for example, takes the sense 'little' from verse 6 and considers verse 10 a verse which ties Matthew's composition to its context. ${ }^{4}$ Similarly, Gnilka takes the word in the concrete sense in 18:4, but includes ordinary Christians in the following verses. ${ }^{5} \mathrm{~A}$ mostly forgotten alternative is that different phases of the text refer to different directions. According to Klostermann the original logion denoted simply children, but here Matthew uses it of ordinary Christians. ${ }^{6}$

2) On the other hand, several commentators have more or less boldly accepted the second alternative, that although $\mu 1$ kpoí may also include children it here means ordinary members of the congregation. Schnackenburg considers them as denoting 'von Jesu gesandten Jünger' (cf. Matt. 10:42; Mark 9:41), ${ }^{7}$ and Hagner speaks of an offence 'toward another disciple'. ${ }^{8}$ Wiefel pays attention to the words used:

3 F. V. Filson, A Commentary on the Gospel according to St. Matthew (London: Black, 1960 [repr. 1967]): 199.

4 R. H. Gundry, Matthew: A Commentary on His Literary and Theological Art (Grand Rapids: Eerdmans, 1982): 364.

5 Gnilka, Matthäusevangelium, 123.

6 E. Klostermann, Das Matthäusevangelium (HNT 4; 2nd edn; Tübingen: Mohr, 1927): 149; Luz, Matthew, 438 calls v. 10b 'a traditional logion'.

7 R. Schnackenburg, Matthäusevangelium, 16,21-28,20 (Würzburg: Echter, 1987): 169.

8 D. A. Hagner, Matthew 14-28 (Word Biblical Commentary 33B; Dallas: Word, 1995): 526. 
$\pi \alpha 1 \delta$ íov in verse 2 , but $\mu 1$ kpós in verses 6 and 10 , which would suggest that children are not the only group referred to. ${ }^{9}$ It was common in early Christianity, for example, for catechumens to be considered 'children' or even 'foetuses', which is attested by, among others, the various passages dealing with Exodus 21:22-25. ${ }^{10}$

Grammatically and logically, both alternatives are possible. So, who was protected by Jesus' warning? On the one hand, children are mentioned in verses $3-4$, but on the other hand, the context also speaks of how every person is important in the congregation. In principle, it is indeed possible that the word had different senses in the source and in Matthew's redaction. The only way to choose between the two alternatives is to further investigate the passage and look at the entire context.

\section{The Religious Background of the Verse}

The commentators refer to numerous Old Testament passages, such as Genesis 48:16, Daniel 10:4-21, to Psalm 91:11 and Tobit 5:6-22; $12: 15,{ }^{11}$ which do not contain anything about a guardian angel given to children, yet generally mention guardian angels (see esp. Tob. 5:17). It is also common to refer to early Jewish texts, often through Billerbeck, or to quote texts mentioned there, ${ }^{12}$ but new texts are also added. For example, Schweizer and Hagner add 1QH 13:20-22 (olim 1QH 5:2022) and 3 Baruch 12:3, and Luz assumes that here, like in 3 Baruch 1213 and 2 Enoch 19:4-5, the angels will be present at the last judgment. ${ }^{13}$ Gnilka adds 2 Maccabees 11:6; 15:22-23 in which people

9 Wiefel, Matthäus, 320. According to Davies and Allison, The Gospel according to Saint Matthew, vol. II: Commentary on Matthew VIII-XVIII (Edinburgh: Clark, 1991): 771, the group referred to were not literally children, and according to Luz, Matthew, 434, all Matthean Christians are 'little ones'.

10 See E. Koskenniemi, 'The Fighting Men and the Unhappy Birth: (Exod. 21,2225)(forthcoming), and E. Koskenniemi, The Exposure of Infants among Jews and Christians in Antiquity, (The Social World of Biblical Antiquity, Second Series 4; Sheffield; Sheffield Phoenix Press, 1991). On the history of interpretation of Matt. 18:10, see Luz, Matthew, 30-31.

11 See W. F. Albright and C. S. Mann, Matthew (AB; New York, London, Toronto, Sydney, Auckland: Doubleday, 1984): 218; Gundry, Matthew, 364; Schnackenburg, Matthäusevangelium, 169-71; Hagner, Matthew, 527.

12 See (H. L. Strack - ) P. Billerbeck, Kommentar zum Neuen Testament aus Talmud und Midrasch 1-6 (München: Beck, 1926-61) I (1982): 780-84; II (1983): 707-708; III (1985): 437-39.

13 Luz, Matthew, 441, also refers to L.A.B. 59,4; T.Jos. 6:7 and to 1. En. 119 b. 
hope for the help of an angel in a particular battle. ${ }^{14}$ The New Testament passages illuminating the issue are not always adequately observed. ${ }^{15}$

It is clear that only a few commentators have noted how strongly angels were present in some areas of early Jewish thought. They have generally referred to Billerbeck and only a few early Jewish texts. ${ }^{16}$ All in all, the investigation of the text has led them to different interpretations. Hagner rejects the view that the passage describes a guardian angel assigned to each individual Christian, and claims that the angels only represent 'the little ones' before the throne of God. ${ }^{17}$ Similarly, Beare overlooks the Jewish background completely and is bold enough to claim:

Nothing in any of the Jewish literature suggests that any angels have special charge over children, or over the weak. ${ }^{18}$

A few commentators have referred to an angel whose mission was to guard children. ${ }^{19}$ However, many of them recognise the idea of a guardian angel given generally to single Christians. Schnackenburg writes as follows:

In der Urkirche setzte sich der Glaube an individuelle Schutzengel (Apg 12:15) und an die Verbindung der Gemeinde mit den Engeln Gottes (1 Kor 11:10; Heb. 12:11; Zuschriften in den Sendschreiben Offb 2:1-3:14) fort. $^{20}$

Wiefel gives a similar interpretation claiming of the 'little ones', moreover, that 'apparently they alone', have an angel ('Schutzgeist')

14 Gnilka, Matthäusevangelium, 131-32.

15 Gundry has collected the relevant material best, referring to Luke 15:10; Matt. 4:6, 11 / Luke 4:9-11, 13; 1 Cor. 11:10; Heb. 1:14 and especially to the role of angels in Matthew $(13: 41 ; 16: 27 ; 24: 31 ; 25: 31 ; 26: 53)$ and to the role of the devil's angels $25: 41$ (Matthew, 364).

16 On the Hellenistic background, see, for example, Plut. Isis Osiris, 26; C. Zintzen, 'Geister (Dämonen) B. Nichtchristlich. III. Östliche Mittelmeerwelt seit dem 4./3. v. C. c. Hellenistische u. kaiserzeitliche Philosophie', RAC 9 (1976): 640-68, esp. 641-42; E. Boring, K. Berger, C. Colpe, Hellenistic Commentary to the New Testament (Nashville: Beck, 1995): 114.

17 Hagner, Matthew, 527.

18 F. W. Beare, The Gospel according to Matthew: A Commentary (Oxford: Blackwell, 1981): 377.

19 Filson writes as follows: 'Angels in Heaven individually represent each of these little ones' (St. Matthew, 200). Although other Christians are also included in his interpretation, children seem to be the first objective. See also Klostermann, Matthäusevangelium, 149.

20 Schnackenburg, Matthäusevangelium, 171. 
representing them before the heavenly Father. ${ }^{21}$ Schweizer considers the idea of a personal guardian angel as first mentioned in Tobit 5, and claims that those angels existed in heaven, and only in later thought, such as in 3 Baruch 12-13, in the Apocalypse of Paul and in Targums, and he sees precisely here the importance of Matthew 18:10 attributing a heavenly guardian to the 'little ones'.$^{22}$ Luz, too, says that Matthew 18:10 clearly attests the idea of an individual guardian angel. ${ }^{23}$

To sum up, the majority of commentators have rejected the interpretation that every Christian has a guardian angel and claimed that this verse has nothing to do with an angel whose mission is to guard children. On the other hand, some commentators have accepted that 'the little ones', ordinary Christians, have a guardian angel, but rejected the interpretation that this verse deals with children. The main task of this article is to ask whether these claims are justified in the light of some early Jewish texts.

\section{Temlakos and Other Punishing Angels}

An angel whose mission is to guard children is mentioned in an early Christian text. We only have fragments of the Apocalypse of Peter, a text written before 180, but after about AD 100. ${ }^{24}$ The first fragment, written in Greek, was discovered in 1886/87 in Akhmim in Egypt, and an Ethiopian version was found soon afterwards (published in 1910). The two versions differ markedly from each other, and most scholars consider the Ethiopian version as the better representative of the original, a view which is strongly represented by Buchholz in his

\footnotetext{
21 Wiefel, Matthäus, 321.

22 E. Schweizer, Das Evangelium nach Matthäus (NTD 1; 3rd edn; Göttingen, 1981): 239.

23 Luz, Matthew, 443. See also W. D. Davies - D. C. Allison, Saint Matthew, 770-71.

24 B. Altaner and A. Stuiber, Patrologie. Leben, Schriften und Lehre der Kirchenväter (8. Aufl.; Freiburg, Basel, Wien: Herder, 1978): 141-42.
}

The writer seems to have known 4 Ezra (about AD 100) and is quoted by Theophilus of Antioch (about 180). D. D. Buchholz, Your Eyes Will Be Opened: A Study of the Greek (Ethiopic) Apocalypse of Peter (SBL Dissertation Series 97; Atlanta: SBL, 1988): 428-39 considers it to be a product of the Johannine circles, which opposed the high Christology. According to him, chapter 2 refers to Bar Kochba as the false Messiah, and the work dates from about 132-35. 
edition of the Ethiopian text and the commentary on it. ${ }^{25}$ The original language of the work is Greek.

The texts tell us about the punishments that the sinners suffer after death. The passage that is interesting for our theme is given in both versions. The Ethiopian fragment goes as follows:

Near this fire is a huge pit, very deep. All sorts of punishments flow into it from everywhere, loathsome menstruations. The women there are swallowed up to their necks, tortured with intense agony. These women abort their children, wiping out the work, which God has moulded. Facing them is another place where the children live, those children, which they kept from living. When the babies call out to God, lightning comes out from them, boring into the eyes of the women who managed their destruction with this adultery.

Above there, other men and women are standing naked. Their children stand facing them in a delightful place. As the children wail, they groan and call out to God against their parents: 'They neglected us and cursed us, and violating your commandment, they put us to death. They cursed the angel who formed us, and they hung us up. They begrudged us the light which you gave to everybody' Their mothers' milk runs from their breasts. It thickens and becomes putrid. Meat-eating animals are in it, and they go in and out of it, and they are punished forever, with their husbands. For they abandoned the law of God, when they killed their children. But the children will be given to the angel Temlakos. Their killers will be punished for ever, because God has required it (8:1-10, tr. by Buchholz).

The post mortem punishment of the women is mentioned in both versions, ${ }^{26}$ but Temlakos only occurs in the Ethiopian fragment. We thus have here a warning combination of children and avenging angels. Temlakos is mentioned in some other early Christian sources, which apparently depend on the Apocalypse. Clement of Alexandria obviously refers to this passage:

Scripture ( $\gamma \rho \alpha \varphi$ í) says that infants which are exposed are delivered to a

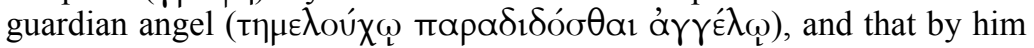
they are trained and reared. 'And they shall be,' it says, 'as the faithful in

25 On two different opinions, see Buchholz, Apocalypse of Peter, 107-109, and for his own view pp. 376-430.

26 The Akhmim fragment, preserved in Greek, contains a short form: 'And near that place I saw another strait place into which the gore and the filth of those who were being punished ran down and became there as it were a lake: and there sat women having the gore up to their necks, and over against them sat many children who were born to them out of due time, crying; and there came forth from them sparks of fire and smote the women in the eyes: and these were the accursed who conceived and caused abortion' (c. 25, trans. by Roberts and Donaldson). 
this world of a hundred years of age'. Wherefore also Peter, in the Revelation, says: 'And a flash of fire, leaping from those infants, and striking the eyes of the women'. For the just shines: forth as a spark in a reed, and will judge the nations.

For instance, Peter says in the Apocalypse, that abortive infants shall share the better fate; that these are committed to a guardian angel

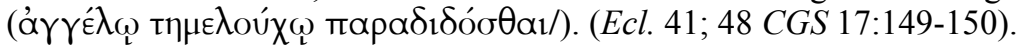

Clement had read the work, and perhaps he refers to several texts, but it is unclear whether he understood the angel better than we do. The Ethiopian 'Temlakos' and the Greek phrase in the dative ó $\gamma \gamma \varepsilon \hat{\varepsilon} \lambda \omega$ $\tau \eta \mu \varepsilon \lambda \circ \chi_{\chi} \omega_{1}$ do not help to reconstruct the wording of the original. Apparently, the writer of the Apocalypse considered Temlakos a name ${ }^{27}$ presumably taken from a Jewish source. Clement, on the other hand, who had seen the Greek version, may have interpreted the word

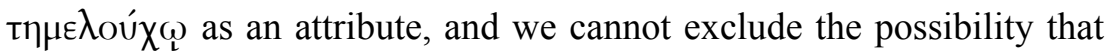
there were more than one of these angels. Methodius, also referring to

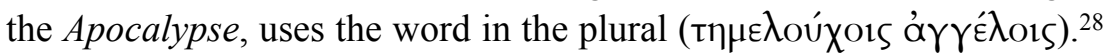
In original Hebrew forms, the name of the angel often explained their mission. Examples are Raphael, Iaoel or Zervihel. ${ }^{29}$ Gray tries to explain the word with the verb $т \eta \mu \varepsilon \lambda \varepsilon$ ' $\omega$, 'to protect, to look after' ${ }^{30}$ However, this only explains the beginning of the word (Gray does not suggest a periphrastic construction with ' $\chi(\omega)$. Clement might have combined this word with the name or the mission of the angel. However, it seems probable that the original word was really a Hebrew name, transmitted to us in Greek and Ethiopian forms. It would apparently require Daniel the Wise to explain the original form and its evolution to 'Temlakos'.

27 Buchholz, Apocalypse of Peter, 321. Buchholz here very briefly refers to Matt. 18:10

28 'Whence, also, we have received from the inspired writings, that those who are

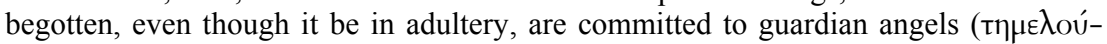

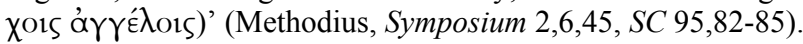

29 On Zervihel, see D. J. Harrington, J. Cazeaux, C. Perrot and P.-M. Bogaert, Pseudo-Philon, Les antiquités bibliques 2. Introduction littéraire, introduction, texte critique et commentaire (SC 229-30; Paris: Cerf, 1976): 160 and D. J. Harrington, 'Pseudo-Philo', OTP 2 (1985): 340, who consider the names Zerviehel / Zeruel only two variants, and trace the name to זרוע ('arm', 'strength'); see also H. Jacobson, A Commentary on Pseudo-Philo's Liber Antiquitatum Biblicarum with Latin Text and English Translation 1 (AGJU 31; Leiden, New York, Köln: Brill, 1996): 792.

30 P. Gray, 'Abortion, Infanticide and the Social Rhetoric of the Apocalypse of Peter', Journal of Early Christian Studies 9 (2001): 326. 
An interesting feature of the text is the mention of the angel who 'formed the children', an idea stemming from the Jewish religion. In earlier times, men could still see God and talk with him, but later he is transcendent and stands in contact with men through angels. The Book of Jubilees distances God from the human spheres and introduces an 'angel of Presence' to the stories about Moses (Jub 1-2). Various functions were attributed to different angels such as Iaoel, Raphael or Zervihel. ${ }^{31}$ Now an angel who formed the children is also mentioned. Although this angel is not mentioned elsewhere in early Jewish texts, it is not difficult to fill in the gaps. The angels take part in God's creative work; true, the fullest account of this is in a Gnostic text that rewrites the creation, and considers the angels bad and creation a crime (Apocryphon Johannis 15-17). In our context, the angel who formed children served God, and hurting children was an offence against him. ${ }^{32}$ The thought is certainly genuinely Jewish.

The angel perfectly fits Jesus' words in Matthew. If this idea was commonly known in early Judaism, Jesus indeed refers to an angel who is in charge of children, just as Rafael's mission was to heal and Zervihel's mission to fight. In this interpretation, the angel, 'Temlakos', not only guards children, but avenges the wrongs done to them. However, although the Apocalypse is apparently a very early Christian work, it clearly postdates Matthew. Are there any arguments that would warrant dating the idea of punishing angels to an earlier time? First, Clement seems to refer to several texts, and secondly, some early Jewish texts may be helpful indeed.

The Greek Apocalypse of Ezra is a Jewish text redacted by a Christian hand, making it impossible to set the date of the work. ${ }^{33}$ The text tells how 'Ezra' saw people punished after their death:

And the prophet said: 'Pity, O Lord, the race of Christians'. And I saw a woman suspended and four wild beasts were sucking upon her breasts. And the angels said to me: 'She begrudged giving her milk but also cast infants into the rivers'. And I saw terrible darkness and night without

31 On the angels named in early Jewish texts, see J. Michl, 'Engel V (Katalog der Engelnamen)', RAC 5 (1962): 65-68.

32 On the Ethiopic passage, see Buchholz, Apocalypse of Peter, 316-22.

33 The work makes use of the Greek version of 4 Ezra, which means that it was not written before 150. The latest possible date of the Christian redaction seems to be 850 ; see M. E. Stone, 'Greek Apocalypse of Ezra' OTP (1983): 563. Stone's words, 'Ezra, Greek Apocalypse of', $A B D 2$ (1992): 729, show how difficult it is to set the date ('It most likely originated sometime during the 1 st millenium, as is evident from its literary affinities'). 
stars or moon. There is there neither young nor old, neither brother with brother nor mother with child nor wife with husbands. And I wept and said: 'O, Lord, Lord, have mercy upon the sinners' (Gk. Apoc. Ezra 5:1$3)$.

The punishing angels are thus present again, implying that the idea of angels punishing the merciless deeds done to children is older than the Apocalypse of Peter, and that it is a genuine Jewish thought. Also, this text is admittedly very late in its present form and, moreover, edited by a Christian hand.

However, the Greek Apocalypse of Ezra is not the first Jewish text connecting the bad treatment of children with punishment. First Enoch contains a passage relevant to our theme. Sinners are generally sharply attacked throughout chapters $91-105$, and a sign of their impiety is that they do not show mercy towards their own children. Moreover, all sins are written down and lead to a severe post mortem punishment of the sinners (1 En. 103:5-8). 1 Enoch does not directly speak of a punishing angel here: the passage says that sinners are tortured in many ways, but does not name the agent. However, angels stand in God's service and make note of good and bad deeds ( 1 En. 98:8; 99:3; 100:10; 104:1). It is also they who apparently perform the punishment (cf. 1 En. 91:5; 102:3). The passage is part of unit $91-105,{ }^{34}$ which was written either in the age of the Hasmoneans, ${ }^{35}$ or earlier, about 170 BC. ${ }^{36}$ Consequently, post mortem punishment, and apparently also the angels who wrote down the crimes and performed the punishment are clearly concepts from pre-Christian times.

34 Scholars define the part of the work differently: G. W. E. Nickelsburg, Jewish Literature between the Bible and the Mishna: A Historical and Literary Introduction (Philadelphia, 1981): 145-50, deals with chapters 92-105 as does R. A. Horsley, 'Social Relations and Social Conflict in the Epistle of Enoch' in For a Later Generation: The Transformation of Tradition in Israel, Early Judaism, and Early Christianity, ed. R. A. Argall et al.) (Harrisburg, 2000): 101. J. C. VanderKam, An Introduction to Early Judaism (Grand Rapids, Michigan, 2001): 119-21 with 91107(108).

35 M. Delcor, 'Jewish Literature in Hebrew and Aramaic in the Greek Era' in The Cambridge History of Judaism. II The Hellenistic Age, ed. W. D. Davies and L. Finkelstein) (Cambridge, London, New York, Port Chester, Melbourne and Sydney 1989): 430-31; S. Uhlig, 'Das äthiopische Henochbuch', JSHRZ 5 (1984): 494.

36 G. Nickelsburg, Jewish Literature, 149-50; J. C. VanderKam, Introduction, 119-21. 


\section{Some New Perspectives Suggested}

Commentators have obviously overlooked the passages speaking of Temlakos. Although his name only occurs in Christian texts, we have good reason to believe that the idea is taken from Jewish sources and that at least the thought of angels punishing merciless deeds done to children antedates the gospel of Matthew. However, it is not obvious how the Jewish background should be observed in the detailed interpretation of Matthew 18:10.

Jesus does not speak of an angel who is in charge of children ( $\dot{o}$

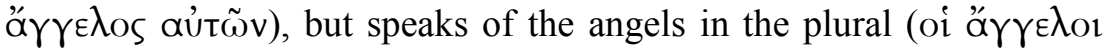

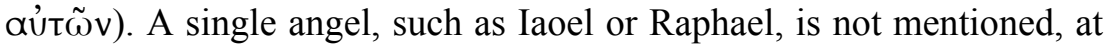
least in the present form of the text. Moreover, it is not certain, although probable, that 'Temlakos' is a name: Clement and Methodius interpreted it otherwise. Several angels are thus mentioned, and they seem to play a similar role in 1 Enoch and in Greek Ezra, to remember merciless deeds and to punish them. In this sense, Luz's short note ${ }^{37}$ seems to point in the right direction, and the angels are supposed to represent Christians when merciless people are punished. At any rate, the interpretation is well suited to the Jewish thought that offences against children are punished at the end of time.

It is not clear whether the verse says that single children or Christians in general have their guardian angels. The verse in its present form and context is clearly open to the interpretation that ordinary Christians are included, too. However, it is possible and even probable that the original logion was more precisely connected to children.

All in all, the Jewish and early Christian texts open new doors, but new questions also. The brief logion does not allow definite conclusions on the detailed role of the angels. They certainly observe children and all godless acts done to them, but this does not necessarily mean that each child has a guardian angel. Apparently a group of very mighty angels (cf. Tob. 12:15) pays special attention to people hurting children in order to punish them after their death.

37 See above n. 13. 


\section{Summary:}

In Matthew 18:10, Jesus speaks of angels who see the face of the Lord. Modern commentators have not reached a consensus on the sense of these words. Some reject the view that single Christians have an individual guardian angel, and many deny in particular that the verse speaks of guardian angels attributed to single children, because the verse not only deals with children but with members of the congregation, ordinary Christians. This article investigates the early Jewish and early Christian backgrounds of Jesus' words and reintroduces Temlakos and other angels, whose mission is to represent children, and who have been widely overlooked by scholars. The article also reflects on some new alternatives for interpretation. 